\title{
Contrast-induced nephropathy in interventional cardiology
}

This article was published in the following Dove Press journal: International Journal of Nephrology and Renovascular Disease 12 July 201 I

Number of times this article has been viewed

\author{
Doron Sudarsky \\ Eugenia Nikolsky \\ Cardiology Department, \\ Rambam Health Care Campus \\ and Technion-Israel Institute \\ of Technology, Haifa, Israel
}

Correspondence: Eugenia Nikolsky Rambam Health Care Campus, Haifa, Israel

Fax +9724854345 I

Tel+9724854218I

Email e_nikolsky@rambam.health.gov.il
Abstract: Development of contrast-induced nephropathy (CIN), ie, a rise in serum creatinine by either $\geq 0.5 \mathrm{mg} / \mathrm{dL}$ or by $\geq 25 \%$ from baseline within the first $2-3$ days after contrast administration, is strongly associated with both increased inhospital and late morbidity and mortality after invasive cardiac procedures. The prevention of CIN is critical if long-term outcomes are to be optimized after percutaneous coronary intervention. The prevalence of CIN in patients receiving contrast varies markedly (from $<1 \%$ to $50 \%$ ), depending on the presence of well characterized risk factors, the most important of which are baseline chronic renal insufficiency and diabetes mellitus. Other risk factors include advanced age, anemia, left ventricular dysfunction, dehydration, hypotension, renal transplant, low serum albumin, concomitant use of nephrotoxins, and the volume of contrast agent. The pathophysiology of CIN is likely to be multifactorial, including direct cytotoxicity, apoptosis, disturbances in intrarenal hemodynamics, and immune mechanisms. Few strategies have been shown to be effective to prevent CIN beyond hydration, the goal of which is to establish brisk diuresis prior to contrast administration, and to avoid hypotension. New strategies of controlled hydration and diuresis are promising. Studies are mixed on whether prophylactic oral $\mathrm{N}$-acetylcysteine reduces the incidence of CIN, although its use is generally recommended, given its low cost and favorable side effect profile. Agents which have been shown to be ineffective or harmful, or for which data supporting routine use do not exist, include fenoldopam, theophylline, dopamine, calcium channel blockers, prostaglandin $\mathrm{E}_{1}$, atrial natriuretic peptide, statins, and angiotensin-converting enzyme inhibitors.

Keywords: contrast-induced nephropathy, contrast media, acute kidney injury, percutaneous coronary intervention

\section{Introduction}

Iodinated contrast agents are being widely utilized for diagnostic and therapeutic purposes. More than 1.2 million cardiac catheterizations are conducted in the US annually. ${ }^{1,2}$ The continuing growth of coronary interventions coupled with an aging population and increasing procedural complexity has resulted in an increased incidence of renal impairment caused by exposure to contrast agents, a disorder known as contrast-induced nephropathy $(\mathrm{CIN}) .^{3}$

\section{Definition and incidence}

Definition of CIN is based on three essential components, ie, deterioration of renal function compared with baseline status, a temporal relationship between decline in renal function and exposure to a contrast agent, and ruling out alternative explanations 
for renal impairment. For many years, due to ease and low cost, assessment of serum creatinine has been a mainstay to characterize renal function, and until recently, the majority of clinical studies used change in serum creatinine to define CIN. Although the definition of CIN varies across the trials, the most commonly used one includes an absolute increase in serum creatinine of $\geq 0.5 \mathrm{mg} / \mathrm{dL}(44.2 \mu \mathrm{mol} / \mathrm{L})$ or $\mathrm{a} \geq 25 \%$ relative increase in serum creatinine from the baseline value at 48-72 hours after exposure to contrast agent in the absence of alternative causes for acute kidney injury. ${ }^{4,5}$

The lack of a uniform definition of CIN led to diversity in the incidence of CIN reported in the peer-reviewed literature. According to the information on contrast media use available from the US Food and Drug Administration, the incidence of renal failure after contrast administration, based on serum creatinine criteria, ranged from $0.6 \%$ to $2.3 \%{ }^{6}$ However, rates of CIN may be as high as $50 \%$, depending on the presence of well characterized risk factors, the most important of which are baseline chronic renal insufficiency and diabetes mellitus. $3,4,7-10$

However, serum creatinine is not an ideal marker of kidney function, for several reasons. First, serum creatinine undergoes tubular secretion into the urinary space. Second, levels of serum creatinine can vary widely depending on a large number of nonrenal factors including but not limited to age, gender, muscle mass, and hydration status. Third, serum creatinine is a relatively late marker of kidney injury, and up to $50 \%$ of kidney function may be lost before serum creatinine rises. Furthermore, serum creatinine does not accurately depict kidney function until steady state has been achieved (up to 2-3 days after injury) and is altered by renal replacement therapies. And last, but not least, depending on the method of measurement, several substances and drugs (eg, ketones, plasma proteins, and cephalosporins) are known to interfere with laboratory measurements of serum creatinine. ${ }^{11-15}$

Given the aforementioned drawbacks of serum creatinine as a measure of renal function injury, there is a call for more sensitive definitions of CIN to be included as a primary outcome in randomized clinical trials of CIN prevention. The role of several novel biomarkers is currently being investigated in patients experiencing acute kidney injury, including CIN.

Cystatin $\mathrm{C}$, a protein member of the cysteine proteinase inhibitor family, is produced at a relatively constant rate by nucleated cells, is freely filtered at the glomerulus, and is then reabsorbed and metabolized by the proximal tubule. ${ }^{16}$ In several settings, including contrast media exposure, cystatin $\mathrm{C}$ has been suggested as a sensitive marker of acute kidney injury. ${ }^{17}$ Compared with serum creatinine, the serum concentration of cystatin $\mathrm{C}$ is less dependent on age, gender, muscle mass, and nutrition, and therefore more reliably predicts deterioration of renal function. ${ }^{18-20}$ Still, serum cystatin $\mathrm{C}$ levels do appear to be altered by several factors other than renal function, including thyroid dysfunction and glucocorticoid therapy. ${ }^{21-23}$

In a study by Briguori et al in 410 patients with preexisting renal dysfunction (estimated glomerular filtration rate $<60 \mathrm{~mL} / \mathrm{min} / 1.73 \mathrm{~m}^{2}$ ) undergoing coronary and/or peripheral procedures using contrast media, a serum cystatin $\mathrm{C}$ increase of $\geq 10 \%$ from baseline at 24 hours postprocedure was the best increment cutoff value for early identification of patients at increased risk of CIN.$^{24}$ In the same study, a serum cystatin $\mathrm{C}$ increase of $\geq 10 \%$ was an independent predictor of all-cause mortality or requirement for permanent dialysis at one year. ${ }^{24}$ Likewise, in the post hoc analysis of the CARE (Cardiac Angiography in Renally Impaired Patients) study, development of CIN after contrast exposure, defined by changes in serum cystatin C of $15 \%, 20 \%$, and $25 \%$ compared with baseline, was associated with an increased incidence of adverse events at one year. ${ }^{25}$

Neutrophil gelatinase-associated lipocalin (NGAL), a member of the lipocalin family, has been recognized to accumulate in the human kidney cortical tubules, blood, and urine after nephrotoxic and ischemic injuries, prompting its evaluation as a biomarker of acute renal injury. ${ }^{26,27}$ In a small series of 25 nondiabetic patients, with normal baseline serum creatinine and undergoing coronary angiography, a significant rise in both serum and urine NGAL and serum cystatin $\mathrm{C}$ was detected several hours after the procedure, with a return to baseline values within 48 hours, while levels of serum creatinine and creatinine clearance remained unchanged after the procedure. ${ }^{28}$ Another study of NGAL as a marker of renal function after elective cardiac catheterization and angiography in 91 children with congenital heart disease showed that NGAL allows early (within two hours after contrast exposure) diagnosis of renal injury. ${ }^{29}$ However, given that the level of NGAL may be increased in several inflammatory conditions, the place of NGAL as a marker of kidney injury needs to be determined further in future trials. ${ }^{30}$

Other markers of kidney injury have potential use in diagnosis of CIN. Kidney injury molecule is a type 1 transmembrane adhesion protein, the expression of which is upregulated in the proximal tubule cells in response to ischemia. A soluble form can be detected in the urine of 
both animal models and in patients suffering from acute kidney injury due to CIN. ${ }^{31,32}$ In patients undergoing coronary angiography, elevated levels of urinary alpha glutathione S-transferase were detected after exposure to contrast media, in the absence of changes in serum creatinine. ${ }^{33}$

\section{Pathogenesis}

The pathogenesis of CIN is still uncertain and is likely to be multifactorial. Contrast-induced renal injury is thought to depend on the formation of free radicals, generated within the acidic environment of the renal medulla. The hyperosmolar stress that accompanies the use of some contrast agents was shown to trigger prompt cellular generation of reactive oxygen species resulting in direct cytotoxicity and apoptosis of renal tubular and glomerular cells. ${ }^{34-36}$

The influence of contrast media on renal hemodynamics may also play a major role in the pathogenesis of CIN. The outer medulla is an area at risk for acute kidney injury given the vulnerability of this region to a decrease in oxygen tension. Several animal studies have documented contrast media-related constriction of the vasa recta supplying the outer medulla, and a decrease in renal medullary blood flow, glomerular filtration rate, red blood cell velocity, and oxygen tension, along with an increase in red blood cell aggregation. ${ }^{37-43}$ In another animal study, the intra-arterial administration of contrast media caused a biphasic response, with a short period of renal hyperperfusion followed by vasoconstriction with subsequent hypoperfusion and, finally, restoration of normal flow within several minutes. ${ }^{44}$ The viscosity of contrast media has been shown to play a differential role in renal hemodynamics. ${ }^{45}$

In patients with chronic kidney disease (serum creatinine $>1.5 \mathrm{mg} / \mathrm{dL}$ ), administration of contrast medium during coronary intervention resulted in a gradual decline in renal blood flow velocity compared with the baseline level. ${ }^{46,47}$ In another small study of 14 patients with chronic renal insufficiency receiving an intravenous bolus of either high osmolar contrast diatrizoate or low osmolar contrast iopamidol, there was an immediate and progressive decline of both renal blood flow and glomerular filtration rate. ${ }^{48}$

The level of endothelin, a strong endogenous vasoconstrictor, was found to be increased after exposure to contrast media, and is believed to be involved in the pathogenesis of CIN. ${ }^{49,50}$ Immunological mechanisms have been implicated as well. ${ }^{49,51}$

Atheroembolic renal disease, also known as atheroembolism, may also contribute to deterioration of renal function after angiographic procedures, and should be considered in the differential diagnosis of acute renal failure after contrast exposure. $^{52}$

\section{Risk factors}

Several major risk factors for the development of CIN have been identified, including baseline chronic renal insufficiency, diabetes mellitus, advanced age, anemia, congestive heart failure, impaired left ventricular systolic function, higher volume of contrast media, procedures performed in the setting of hemodynamic instability, and the use of drugs with nephrotoxic properties close to contrast media exposure (Table 1). , $^{3,7,7,8,53-60}$

\section{Chronic renal insufficiency}

Preprocedural renal function impairment is the strongest predictor for CIN. $3,4,7,10,58,61-63$ The higher the baseline serum creatinine value, the greater the risk of CIN. ${ }^{4,58}$ Patients with preprocedural substantial renal function impairment have a more than tenfold increased risk of developing CIN than patients with normal or near normal preprocedural renal function. ${ }^{63-66}$

\section{Diabetes mellitus}

In diabetics with preserved renal function and no other risk factors, the rates of CIN are usually moderately increased or even comparable with those of the healthy population.

Table I Factors associated with development of contrast-induced nephropathy

\begin{tabular}{|c|c|}
\hline Nonmodifiable & Modifiable \\
\hline \multicolumn{2}{|l|}{ Patient-related factors } \\
\hline Advanced age & Anemia \\
\hline Diabetes mellitus & Intravascular volume depletion \\
\hline $\begin{array}{l}\text { Preexisting chronic kidney } \\
\text { disease with/without chronic } \\
\text { renal insufficiency }\end{array}$ & $\begin{array}{l}\text { Concomitant use of nephrotoxic } \\
\text { agents/drugs }^{\mathrm{a}}\end{array}$ \\
\hline Congestive heart failure & Hypoalbuminemia (<3.5 g/dL) \\
\hline Low cardiac output & $\begin{array}{l}\text { Periprocedural systemic hypotension/ } \\
\text { hemodynamic instability }\end{array}$ \\
\hline \multicolumn{2}{|l|}{ Renal transplant } \\
\hline \multicolumn{2}{|l|}{ Procedure-related factors } \\
\hline $\mathrm{PCl}$ performed in ACS setting & High volume of contrast media \\
\hline \multirow[t]{4}{*}{ Emergent intervention } & $\begin{array}{l}\text { High-osmolality and ionicity of } \\
\text { contrast media }\end{array}$ \\
\hline & $\begin{array}{l}\text { Multiple administration of contrast } \\
\text { media within } 72 \text { hours }\end{array}$ \\
\hline & Intra-aortic balloon pump \\
\hline & $\mathrm{PCl}$-related blood loss \\
\hline
\end{tabular}

Note: ${ }^{2}$ Nonsteroidal anti-inflammatory drugs, cyclosporine, aminoglycosides, cisplatinum.

Abbreviations: $\mathrm{PCl}$, percutaneous coronary intervention; $\mathrm{ACS}$, acute coronary syndrome. 
However, diabetic patients with preprocedural renal impairment have a substantially increased risk of CIN and need for renal replacement therapy.,10,67-69

\section{Older age}

Older age is strongly associated with CIN. Patients older than 75 years have an almost twofold increase in risk of CIN compared with younger patients. ${ }^{56}$ Age-related decrease in glomerular filtration rate, tubular secretion, and concentrating ability, and a higher prevalence of chronic kidney disease, anemia, and congestive heart failure, contribute to the increased incidence of CIN in the elderly.

\section{Anemia and blood loss}

Anemia is an independent predictor of CIN ${ }^{56}$ Lower baseline hematocrit increases the risk of CIN for any given estimated glomerular filtration rate level, and patients combining both low baseline hematocrit and low estimated glomerular filtration rate are at the highest risk of developing CIN (Figure 1). The rates of CIN increase also with an incremental periprocedural drop in hematocrit. ${ }^{59}$

\section{Volume of contrast agent}

Deterioration of renal function after contrast exposure correlates closely with the volume of contrast media, the only modifiable risk factor for CIN. Still, a broad range of contrast volume (from $<100 \mathrm{~mL}$ to $>800 \mathrm{~mL}$ ) may increase the risk of CIN, depending mainly on patient characteristics, clinical scenarios, and CIN definition. $3,4,7,8,53,56-58,61,67,69-74$ In one trial, the cutoff dose of contrast below which there were no cases of acute renal failure requiring dialysis after coronary intervention was $100 \mathrm{~mL}^{3}$ However, in patients with both chronic renal insufficiency and diabetes mellitus, even less than $100 \mathrm{~mL}$ of contrast agent may cause CIN. ${ }^{69}$ As shown in several series, the ratio of contrast volume to baseline estimated glomerular filtration rate may be a stronger predictor of CIN than contrast volume alone. ${ }^{75-78,79}$

\section{Properties of contrast media}

Iodine-containing agents are classified by their iodine content (quantity of iodine per mL of solution), osmolarity (hyperosmolar versus low osmolar versus iso-osmolar), level of ionization (ionic versus nonionic), viscosity, and degree of polymerization (monomeric versus dimeric, see Table 2). The properties of contrast media contribute to the incidence of CIN. Several randomized clinical trials have assessed the impact of contrast media osmolarity on the incidence of CIN. In patients with preexisting renal impairment, ionic high osmolar contrast media caused a higher degree of renal injury compared with nonionic low osmolar contrast media. ${ }^{67,80-82}$ However, there has been ongoing debate as to whether iso-osmolar contrast media provides benefit over

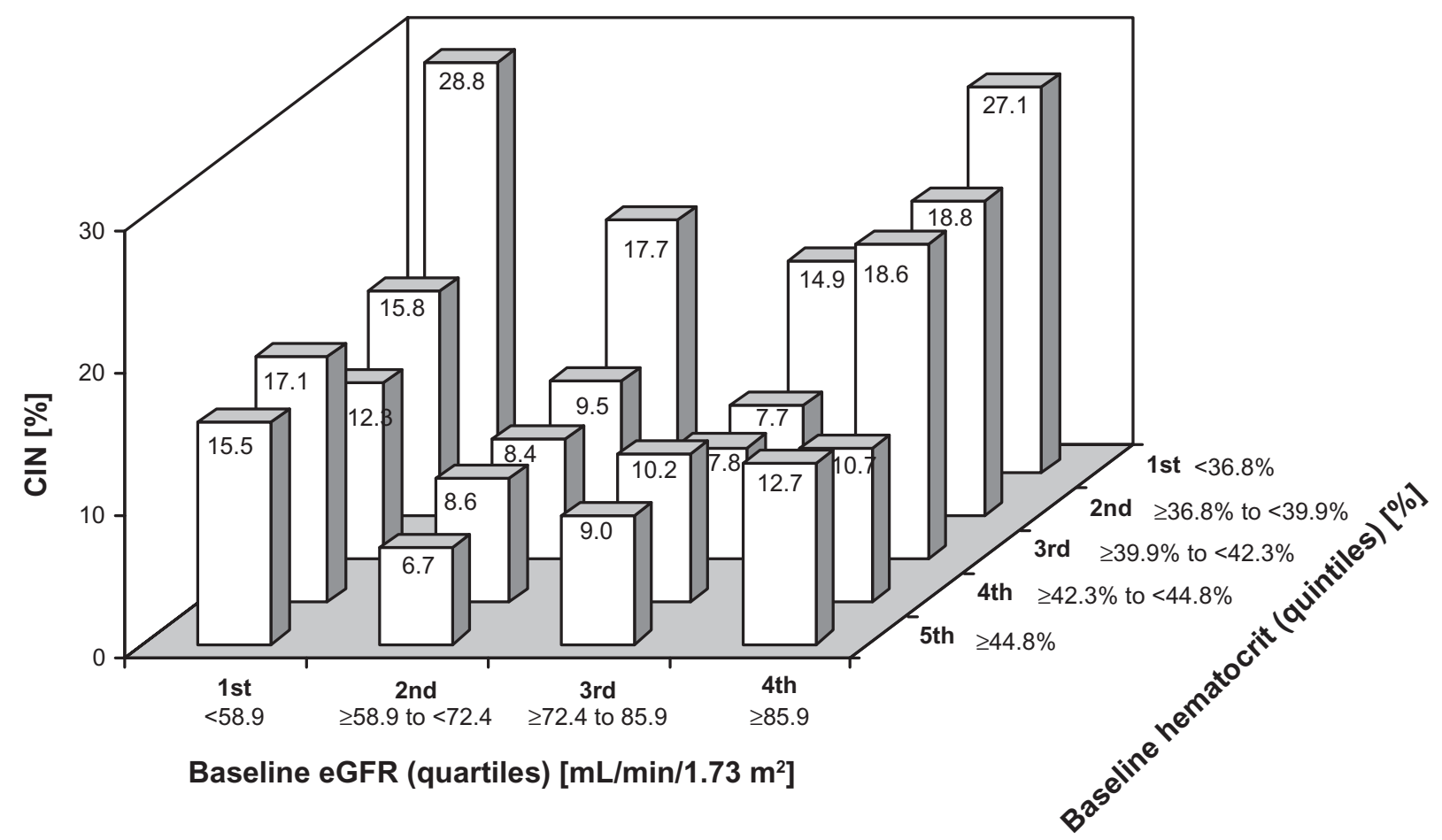

Figure I Association between baseline estimated glomerular filtration rate (eGFR), baseline hematocrit and risk for development of contrast-induced nephropathy (CIN). 
Table 2 Properties of contrast media

\begin{tabular}{|c|c|c|c|c|c|c|c|}
\hline $\begin{array}{l}\text { Generic } \\
\text { name }\end{array}$ & Trade name & Polymerization & $\begin{array}{l}\text { Osmolarity } \\
\text { category }\end{array}$ & $\begin{array}{l}\text { Osmolality } \\
\left.\text { (mOsm/kg } \mathrm{H}_{2} 0\right)\end{array}$ & Ionicity & $\begin{array}{l}\text { lodine content } \\
(\mathrm{mg} / \mathrm{mL})\end{array}$ & $\begin{array}{l}\text { Viscosity } \\
\left(\mathrm{cP} @ 37^{\circ}\right)\end{array}$ \\
\hline Diatrizoate & Renografin ${ }^{\circledR}-76$ & Monomeric & High osmolar & 1,940 & lonic & 370 & 9.1 \\
\hline loxaglate & Hexabrix $^{\circledR}$ & Dimeric & Low osmolar & 600 & lonic & 320 & 7.5 \\
\hline lohexol & Omnipaque ${ }^{\circledR}$ & Monomeric & Low osmolar & 844 & Nonionic & 350 & 10.4 \\
\hline lopamidol & Isovue $^{\circledR}$ & Monomeric & Low osmolar & 796 & Nonionic & 370 & 9.4 \\
\hline loversol & Opitray ${ }^{\circledR}$ & Monomeric & Low osmolar & 702 & Nonionic & 320 & 5.8 \\
\hline lopromide & Ultravist $^{\circledR}$ & Monomeric & Low osmolar & 774 & Nonionic & 370 & 9.5 \\
\hline lobitridol & Xenetix $^{\circledR}$ & Monomeric & Low osmolar & 915 & Nonionic & 350 & 10.0 \\
\hline lomeprol & lomeron ${ }^{\circledR}$ & Monomeric & Low osmolar & 618 & Nonionic & 350 & 7.0 \\
\hline lodixanol & Visipaque $^{\circledR}$ & Dimeric & Iso-osmolar & 290 & Nonionic & 320 & 11.8 \\
\hline
\end{tabular}

low osmolar contrast media in terms of renal protection in patients undergoing contrast media exposure. The data from several comparative trials have yielded inconsistent results. In the NEPHRIC (Nephrotoxicity in High-Risk Patients Study of Iso-Osmolar and Low-Osmolar Non-Ionic Contrast Media) study performed in 129 patients with diabetes and baseline renal insufficiency undergoing cardiac and aortofemoral angiography, the nonionic isotonic dimer, iodixanol-320 (osmolality $290 \mathrm{mOsm} / \mathrm{kg} \mathrm{H}_{2} \mathrm{O}$ ), was associated with lower rates of CIN than the nonionic low osmolar monomer, iohexol-350 (osmolality $780 \mathrm{mOsm} / \mathrm{kg} \mathrm{H}_{2} \mathrm{O}$ ). ${ }^{83}$ Similarly, in 300 patients with serum creatinine $\leq 60 \mathrm{~mL} / \mathrm{min}$ in the RECOVER (Renal Toxicity Evaluation and Comparison between Visipaque and Hexabrix in Patients with Renal Insufficiency Undergoing Coronary Angiography) study, iodixanol was significantly less nephrotoxic than the ionic dimer low osmolar contrast ioxaglate (osmolality $\left.600 \mathrm{mOsm} / \mathrm{kg} \mathrm{H}_{2} \mathrm{O}\right) .{ }^{84}$ However, this was not confirmed in a larger prospective, randomized trial comparing low osmolar contrast iodixanol with low osmolar contrast iopamidol in 526 patients with diabetes mellitus and impaired baseline kidney function undergoing coronary angiographic procedures. ${ }^{85}$ Both the median peak in serum creatinine and the rates of CIN did not differ between the two study groups. ${ }^{85}$ Likewise, in the prospective randomized CARE trial, the rates of CIN, defined by multiple endpoints, were not different after intraarterial administration of low osmolar contrast iopamidol (osmolality $796 \mathrm{mOsm} / \mathrm{kg} \mathrm{H}_{2} \mathrm{O}$ ) or iodixanol in patients with moderate to severe chronic kidney disease. ${ }^{5}$ Furthermore, in the randomized ICON (Ionic versus Non-ionic Contrast to Obviate Worsening Nephropathy after Angioplasty in Chronic Renal Failure Patients) study performed in high-risk patients undergoing coronary angiographic procedures, use of nonionic low osmolar contrast iodixanol did not reduce renal deterioration in patients with renal impairment compared with ionic low osmolar contrast ioxaglate. ${ }^{86}$
The possible role for viscosity of contrast media in the pathogenesis of CIN was assessed in an animal model in which effects on renal hemodynamics of iopromide were compared with iodixanol, a contrast agent with relatively high viscosity and low osmolality. ${ }^{45}$ While both types of contrast media transiently increased renal blood flow, administration of contrast agent with higher viscosity was associated with decreased renal medullary blood flux, erythrocyte concentration, and $\mathrm{pO}_{2}$ content.

\section{Readministration of contrast media}

Certain clinical scenarios require repeat exposure to contrast media within a short time, increasing the risk of CIN. While there are no studies on the ideal timing for repeat contrast exposure, the time frame of 3 weeks seems reasonable given that, in the majority of CIN cases, renal function restores within this period. ${ }^{87}$

\section{Combination of several risk factors}

Patients undergoing contrast exposure have marked variation in CIN risk due to a combination of two or more risk factors. The risk of development of CIN following percutaneous coronary intervention has been shown to rise remarkably with the number of risk factors present. A simple risk score based on eight baseline measures identifies patients at increased risk for CIN/dialysis and subsequent one-year mortality, for whom rigorous preventive strategies should be implemented (Table 3). ${ }^{56,88}$

\section{Serum creatinine trajectory after contrast exposure}

Typically contrast media causes renal dysfunction within the first 12-24 hours, and serum creatinine reaches a peak at three days after contrast exposure. Patients with a $<0.5 \mathrm{mg} / \mathrm{dL}$ rise in serum creatinine within the first 24 hours of contrast exposure are unlikely to develop CIN. ${ }^{66}$ 
Table 3 Risk prediction score for the development of contrastinduced nephropathy and renal failure requiring dialysis ${ }^{35}$

\begin{tabular}{|c|c|c|}
\hline \multicolumn{2}{|l|}{ Risk factors } & Integer score \\
\hline \multicolumn{2}{|l|}{ Hypotension $^{\mathrm{a}}$} & 5 points \\
\hline \multicolumn{2}{|c|}{ Use of intra-aortic balloon pump } & 5 points \\
\hline \multicolumn{2}{|c|}{ Congestive heart failure ${ }^{\mathrm{b}}$} & 5 points \\
\hline \multicolumn{2}{|c|}{ Age $>75$ years } & 4 points \\
\hline \multicolumn{2}{|c|}{ Anemia $^{c}$} & 3 points \\
\hline \multicolumn{2}{|c|}{ Diabetes mellitus } & 3 points \\
\hline \multicolumn{2}{|c|}{ Volume of contrast media } & I point for each $100 \mathrm{~mL}$ \\
\hline \multicolumn{2}{|c|}{$\mathrm{SCr}>1.5 \mathrm{mg} / \mathrm{dL}$} & 4 points \\
\hline \multicolumn{3}{|c|}{ or } \\
\hline \multirow{3}{*}{\multicolumn{2}{|c|}{$e G F R^{d}<60 \mathrm{~mL} / \mathrm{min} / 1.73 \mathrm{~m}^{2}$}} & 2 points for $40-60$ \\
\hline & & 4 points for $20-40$ \\
\hline & & 6 points for $<20$ \\
\hline \multicolumn{3}{|c|}{ Risk assessment } \\
\hline Risk score & Risk of CIN & Risk of dialysis \\
\hline$<5$ points & $7.5 \%$ & $0.04 \%$ \\
\hline $6-10$ points & $14 \%$ & $0.12 \%$ \\
\hline $11-16$ points & $26.1 \%$ & $1.09 \%$ \\
\hline$>16$ points & $57.3 \%$ & $12.6 \%$ \\
\hline
\end{tabular}

Notes: aHypotension: systolic blood pressure $<80 \mathrm{mmHg}$ for at least one hour requiring inotropic support with medications or intra-aortic balloon pump within 24 hours periprocedurally; ${ }^{b}$ congestive heart failure (New York Heart Association functional class III/IV and/or history of pulmonary edema); canemia (baseline hematocrit value $<39 \%$ for men and $<36 \%$ for women); ${ }^{d}$ eGFR $\left(\mathrm{mL} / \mathrm{min} / 1.73 \mathrm{~m}^{2}\right)=$ $186.3 \times(\mathrm{sCrCIN})^{-1.154} \times(\text { age })^{-0.203} \times(0.742$ if female $) \times(1.210$ if African-American $)$. Abbreviations: eGFR, estimated glomerular filtration rate; $\mathrm{CIN}$, contrast-induced nephropathy; $\mathrm{SCr}$, serum creatinine.

In most cases, the decline in renal function is mild and transient, with recovery of renal function starting within 3-5 days. After 1-3 weeks, serum creatinine usually returns to the baseline value or resumes a new baseline level., ${ }^{7} 8$ However, some patients have a persistent decline in renal function and subsequently require renal replacement therapy. As mentioned previously, this is most likely to occur in patients with preexisting renal dysfunction and/or multiple CIN risk factors. ${ }^{7,69,87,90}$

\section{Implications of contrast-induced nephropathy}

The development of CIN after diagnostic coronary angiography and/or percutaneous interventions is associated with prolonged hospitalization, a marked increase in morbidity, inhospital mortality, and costs. ${ }^{3,4,25,53,57,58,61-63}$ Development of CIN also correlates with late morbidity and mortality. $3,4,25,53,61,63$

Contrast-induced nephropathy is the third most common cause of acute renal failure in hospitalized patients. ${ }^{91}$ Nearly all cases of CIN reflect mild transient impairment of renal function, with dialysis needed in a small proportion of patients. ${ }^{87}$ However, in selected high-risk subgroups of patients, such as those with preexisting renal failure or diabetes, up to $7 \%$ require temporary dialysis or progress to end-stage renal disease. ${ }^{3,4,58,61,63}$ Once temporary dialysis is initiated, $13 \%-50 \%$ of patients will require permanent renal replacement therapy. ${ }^{3,61}$ Inhospital mortality is extremely high in patients requiring dialysis after percutaneous intervention (37\% in a study by McCullough et $\mathrm{al}^{3}$ and $39 \%$ in the study by Freeman et $\mathrm{al}^{58}$ ).

\section{Prevention}

Given the negative prognostic impact of CIN, every attempt should be made to reduce its occurrence. The best approach to prevent CIN is to identify at-risk patients, provide adequate periprocedural hydration, and minimize the amount of contrast administered. Multiple preventive measures have been evaluated, with very few of them being efficient in reducing CIN rates (Table 4).

\section{Hydration}

Adequate periprocedural hydration is a key component of preservation of renal function in patients undergoing contrast media exposure. The goal of hydration is maintenance of sufficient intravascular volume to increase renal perfusion, establishment of adequate diuresis prior to contrast media administration, and avoidance of hypotension.

The positive effect of adequate hydration in reducing rates of CIN was first established in a randomized study by Solomon et al. Among 78 patients with chronic renal

Table 4 Strategies evaluated for contrast-induced nephropathy risk reduction

\begin{tabular}{ll}
\hline Preventive strategies & Efficacy \\
\hline Pharmacologic strategies & \\
Hydration & Beneficial \\
Sodium bicarbonate & Inconsistent data \\
Furosemide & May be harmful \\
Mannitol & May be harmful \\
N-acetylcysteine & Inconsistent data \\
Dopamine & No benefit \\
Fenoldopam & No benefit \\
Theophylline/aminophylline & Inconsistent data \\
Calcium channel blockers & Inconsistent data \\
ACE inhibitor/angiotensin receptor blocker & Inconsistent data \\
Atrial natriuretic peptide & No benefit \\
Prostaglandin EI & May be beneficial \\
Statins & May be beneficial \\
Nonpharmacologic strategies & \\
Hemodialysis & Inconsistent data \\
Hemofiltration & May be beneficial \\
Benephit ${ }^{\text {TM }}$ infusion system & May be beneficial \\
RenalGuard ${ }^{\circledR}$ system & May be beneficial \\
\hline
\end{tabular}

Abbreviation: ACE, angiotensin-converting enzyme. 
insufficiency undergoing angiography, hydration with $0.45 \%$ saline $(1 \mathrm{~mL} / \mathrm{kg} /$ hour for 12 hours preprocedure and postprocedure, $\mathrm{n}=28$ patients) provided better protection against renal function deterioration than hydration with $0.45 \%$ saline plus mannitol ( $\mathrm{n}=25$ patients) or furosemide $(\mathrm{n}=25$ patients, $P=0.02$ for saline versus saline plus furosemide group). ${ }^{92}$ Several subsequent studies examined the optimal mode, timing, duration, and intensity of hydration. ${ }^{83,92-96}$

\section{Mode of hydration}

There is no consensus on the best mode of hydration to prevent CIN. In a small study of 36 patients and a larger study of 312 patients with mild-to-moderate renal failure, oral and intravenous fluid administration had similar protective effects against CIN. ${ }^{95,97}$ On the other hand, in the randomized study by Trivedi et al of 53 patients, CIN developed almost 10 -fold more frequently in patients who received oral versus intravenous hydration (34.6\% versus $3.7 \%, P=0.005) .{ }^{93}$ Finally, in a retrospective analysis by Clavijo et al, rapid intra-arterial administration of $1000 \mathrm{~mL}$ of $5 \%$ dextrose immediately before catheterization was associated with a lower rate of CIN compared with standard intravenous hydration $(1.4 \%$ versus $5.7 \%$, respectively, $P=0.03) .{ }^{98}$

\section{Isotonic saline versus half-isotonic saline}

In a study by Mueller et al, intravenous administration of isotonic saline was found to be superior, compared with half-isotonic saline, in reducing the rates of CIN after percutaneous coronary intervention $(0.7 \%$ versus $2 \%$, respectively, $P=0.04$ ). In a subgroup analysis, isotonic hydration was especially beneficial in women $(0.6 \%$ versus $5.1 \%$ ), patients with diabetes mellitus ( $0 \%$ versus $5.5 \%)$ and patients receiving high $(\geq 250 \mathrm{~mL})$ volumes of contrast. ${ }^{96}$

\section{Continuous versus bolus hydration}

In the randomized OTHER CAN (Optimal Timing of Hydration to Erase Contrast-Associated Nephropathy) study performed in 63 patients with moderate renal insufficiency undergoing elective cardiac catheterization, $\mathrm{CIN}$ rates tended to be lower $(P=0.14)$ in the group receiving overnight intravenous hydration compared with the group receiving bolus hydration..$^{99}$ In another small study of 39 patients with preprocedural normal renal function undergoing an angiographic procedure randomized to receive either $300 \mathrm{~mL}$ of normal saline for the duration of contrast exposure or at least $2000 \mathrm{~mL}$ normal saline intravenously 12 hours before and after contrast media administration, CIN occurred significantly more frequently in patients who received bolus hydration. ${ }^{100}$

\section{Regimens in specific patient populations}

There is no uniform standard to guide hydration in patients undergoing contrast exposure, and the practice varies across the institutions. However, it is important to bear in mind that certain clinical scenarios, namely the presence of reduced left ventricular function and chronic renal insufficiency, require cautious fluid administration. One of the commonly recommended hydration regimens is $1 \mathrm{cc} / \mathrm{kg} / \mathrm{hour}$ of normal saline for 12 hours before and after angiography for patients with normal ejection fraction; for patients with moderately or severely reduced ejection fraction, a recommended hydration practice includes volume replacement matching the urine output to maintain euvolemic state for 12 hours preprocedure and postprocedure. According to European guidelines for myocardial revascularization, all patients with chronic kidney disease undergoing diagnostic catheterization should receive preventive intravenous hydration with isotonic saline, to be started at least 12 hours before angiography and continued for at least 24 hours afterwards, in order to reduce the risk of CIN. ${ }^{101}$ The amount of contrast media delivered in these patients should not exceed $4 \mathrm{~mL} / \mathrm{kg} .{ }^{101}$

\section{Use of sodium bicarbonate}

Alkalinizing of the urine by sodium bicarbonate is thought to reduce contrast-induced renal injury by reducing the amount of $\mathrm{pH}$-dependent free radicals. Several studies have been conducted to assess the efficacy of sodium bicarbonate in reduction of CIN rates, and provided conflicting results. In three prospective, randomized studies, preventive hydration with sodium bicarbonate provided better protection against CIN than an alternative hydration regimen. ${ }^{102-104}$ However, in the largest randomized trial, by Brar et al, including 353 patients with baseline estimated glomerular filtration rate $\leq 60 \mathrm{~mL} / \mathrm{min} / 1.73 \mathrm{~m}^{2}$, and at least one risk factor for CIN (diabetes, hypertension, history of chronic heart failure, or age older than 75 years), hydration with sodium bicarbonate provided no benefit. ${ }^{105}$ Moreover, in a large retrospective multivariate analysis from the Mayo Clinic, treatment with sodium bicarbonate was associated with an increased CIN risk (odds ratio 3.10, $P<0.001$ ). ${ }^{106}$

\section{Forced diuresis}

Intensive hydration combined with a diuretic (forced diuresis) is aimed at creating and maintaining a high urine output, allowing rapid elimination of contrast agent and reducing its toxic effects. ${ }^{107}$ Several studies assessing the efficacy of forced diuresis to prevent CIN have yielded conflicting results. In a small, previously mentioned, randomized study 
by Solomon et al, hydration with half-isotonic saline was superior to hydration with half-isotonic saline plus mannitol or hydration with half-isotonic saline plus furosemide. ${ }^{92}$ In the randomized PRINCE (Prevention of Radiocontrast Induced Nephropathy Clinical Evaluation) study in 98 patients, forced diuresis using intravenous crystalloid, furosemide, mannitol, and low-dose dopamine was compared with intravenous crystalloid hydration alone. ${ }^{108}$ Intravenous fluid replacement was performed, with the volume matching the urine output. According to the study results, despite a higher urine flow rate over the 24 hours after contrast exposure in the group treated with forced diuresis compared with the group that received routine hydration, there was only a modest benefit in reduction of CIN in favor of forced diuresis. Yet, in a subgroup of patients with urine flow rates $>150 \mathrm{~mL} /$ hour postprocedure from the forced diuresis group, the CIN incidence was more than two times lower compared with patients who received routine hydration $(21.6 \%$ versus $45.9 \%, P=0.03)$. Noteworthy is that matching fluid intake and urine output in the PRINCE study started only after contrast agent exposure. Thus, the patients might have had a depleted intravascular volume for the duration of time prior to the start of matched fluid replacement. ${ }^{108}$

In a small trial by Weinstein et al in 18 patients, the addition of furosemide to intravenous hydration prior to systemic exposure to contrast media caused significant deterioration of renal function, while no change occurred in the group receiving hydration alone. ${ }^{109}$ Finally, in a study by Dussol et al in 312 patients with chronic renal insufficiency (mean estimated glomerular filtration rate $37 \mathrm{~mL} / \mathrm{min} / 1.73 \mathrm{~m}^{2}$ ) exposed to contrast media, the addition of furosemide to intravenous hydration did not confer any additional benefit. ${ }^{97}$

The concept of forced diuresis to prevent CIN in highrisk patients with chronic renal insufficiency has been further developed in studies assessing a novel automatic RenalGuard $^{\circledR}$ system (PLC Systems Inc, Franklin, MA) to provide controlled hydration. The system is designed to measure urine output and to replace it with an equal volume of intravenous saline solution. Such matched fluid replacement aims at maintaining an individual intravascular fluid volume and minimizing the risk of either overhydration or underhydration. The randomized MYTHOS (Induced Diuresis With Matched Hydration Therapy Compared to Standard Overnight Hydration in the Prevention of Contrast Induced Nephropathy) trial evaluated the effectiveness of this controlled hydration system in reduction of CIN rates in 135 patients with baseline renal insufficiency (estimated glomerular filtration rate $<60 \mathrm{~mL} / \mathrm{min} / 1.73 \mathrm{~m}^{2}$ ) undergoing elective or urgent percutaneous coronary intervention, assigned to forced diuresis using automated matched hydration therapy provided by the system or standard overnight hydration ( $1 \mathrm{~mL} / \mathrm{kg} /$ hour preprocedure and postprocedure). ${ }^{110}$ The controlled hydration protocol provided by the system included matched fluid replacement started approximately 90 minutes before, and was maintained during the procedure and up to four hours following percutaneous coronary intervention, and an initial bolus of $250 \mathrm{~mL}$ of normal saline over 30 minutes followed by intravenous bolus of furosemide $0.5 \mathrm{mg} / \mathrm{kg}$ when $>300 \mathrm{~mL} /$ hour urine output was obtained. The use of the system was associated with a trend towards lower rates of CIN ( $6 \%$ versus $17 \%, P=0.06$ ) and a significantly lower incidence of inhospital major adverse cardiac events $(6 \%$ versus $24 \%$ respectively, $P=0.008) .{ }^{110}$

The same hydration protocol using the controlled hydration system as that used in the MYTHOS study is currently being further assessed in the randomized openlabel REMEDIAL II (Renal Insufficiency Following Contrast Media Administration II Trial) trial in approximately 270 patients with advanced renal insufficiency (baseline estimated glomerular filtration rate $\leq 30 \mathrm{~mL} / \mathrm{min} / 1.73 \mathrm{~m}^{2}$ or high baseline [ $\geq 11$ ] CIN risk score ${ }^{56}$ ) scheduled for coronary or peripheral angiography with or without angioplasty. ${ }^{111}$ The control group includes patients who receive intravenous hydration with sodium bicarbonate along with oral administration of $\mathrm{N}$-acetyl-cysteine.

\section{Pharmacologic agents for prevention of CIN $\mathrm{N}$-acetylcysteine}

There have been multiple studies and meta-analyses assessing the ability of the thiol-containing antioxidant, $\mathrm{N}$-acetylcysteine, to prevent CIN. In the first randomized placebo-controlled study, by Tepel et al in 83 patients exposed to contrast media, prophylactic oral administration of $\mathrm{N}$-acetylcysteine along with hydration was superior to hydration alone in preventing CIN in patients with elevated baseline serum creatinine levels, with rates of $2 \%$ in the $\mathrm{N}$-acetylcysteine group compared with $21 \%$ in controls. ${ }^{112}$ The subsequent APART (Acetylcysteine to Prevent Angiography-related Renal Tissue injury) trial, including 54 patients and using a similar design, confirmed that CIN occurred in $8 \%$ of patients in the oral $\mathrm{N}$-acetylcysteine group versus $45 \%$ in the placebo group. ${ }^{113}$ However, several other studies did not support the efficacy of $\mathrm{N}$-acetylcysteine in preventing CIN. In a randomized study by Briguori et al in 183 patients, oral $\mathrm{N}$-acetylcysteine plus hydration failed to 
show a significant difference in CIN rates compared with hydration alone. ${ }^{114}$ In another randomized study by Webb et al in 487 patients with impaired renal function, intravenous $\mathrm{N}$-acetylcysteine was ineffective in preventing CIN. ${ }^{115}$ Likewise, in the prospective, single-blinded, randomized LIPSIA-N-ACC (Leipzig Immediate PercutaneouS Coronary Intervention Acute Myocardial Infarction N-ACC) trial in 251 patients undergoing primary angioplasty for ST-segment elevation myocardial infarction, high-dose intravenous $\mathrm{N}$-acetylcysteine (1200 mg twice daily for 48 hours) did not reduced rates of CIN compared with placebo (14\% versus $20 \%$, respectively, $P=0.28) .{ }^{116}$ Finally, the large, multicenter randomized, placebo-controlled ACT (Acetylcysteine for Contrast Induced Nephropathy) trial, reported at the 2010 American Heart Association scientific sessions, failed to demonstrate a protective role for $\mathrm{N}$-acetylcysteine in CIN reduction. ${ }^{117}$ This study included 2308 patients with at least one CIN risk factor (age $>70$ years, chronic renal insufficiency, diabetes mellitus, congestive heart failure, left ventricular ejection fraction $\leq 45 \%$, or shock) from 46 hospitals across Brazil. Patients were randomized to receive either oral $\mathrm{N}$-acetylcysteine $1200 \mathrm{mg}$ twice daily, with two doses given before the procedure and two doses given after the procedure, or to placebo. The primary endpoint, defined as $\geq 25 \%$ elevation of serum creatinine above baseline 48-96 hours after angiography, occurred in $12.7 \%$ of patients in both groups $(P=0.97)$. Rates of other endpoints, including serum creatinine elevation $>0.5 \mathrm{mg} / \mathrm{dL}$ (N-acetylcysteine $3.9 \%$ versus placebo $3.8 \%, P=0.85$ ) and doubling in serum creatinine compared with baseline value ( $1.1 \%$ versus $1.5 \%$, respectively, $P=0.41)$ were also similar between the groups.

An important observation on the apparent lack of efficacy of $\mathrm{N}$-acetylcysteine in prevention of CIN has been provided in the prospective study by Hoffmann et al in 50 healthy volunteers with normal renal function. ${ }^{118}$ In this study, the volunteers received $\mathrm{N}$-acetylcysteine (four oral doses of $600 \mathrm{mg}$ every 12 hours) in the absence of administration of contrast media. According to the results, four hours after the last dose of $\mathrm{N}$-acetylcysteine, there was a small but significant decrease in mean serum creatinine and urea concentrations and a significant increase in estimated glomerular filtration rate. However, levels of cystatin $\mathrm{C}$ remained unchanged after $\mathrm{N}$-acetylcysteine administration. Given that cystatin $\mathrm{C}$ is a more reliable marker of deterioration of renal function, the authors concluded that creatinine metabolism is likely to be affected by $\mathrm{N}$-acetylcysteine, questioning the role of $\mathrm{N}$-acetylcysteine in prevention of CIN. ${ }^{118}$

\section{Dopamine}

Decreased renal blood flow due to vasoconstriction has been suggested as a contributory factor to the development of CIN. Given that low-dose dopamine has a dilatory effect on the renal vasculature, it may potentially have a renoprotective effect. However, dopamine failed to show a protective effect on renal function in patients undergoing contrast media exposure, and was even associated with a deleterious effect on the severity of renal failure and its duration. ${ }^{119,120}$

\section{Fenoldopam}

Fenoldopam is a selective, dopamine-1 receptor agonist that augments renal plasma flow. In a pilot trial, patients suffering from chronic renal failure (baseline serum creatinine $2.5-5.0 \mathrm{mg} / \mathrm{dL}$ ) and undergoing angiography, were randomized to a combination of fenoldopam and hydration or hydration alone. The administration of fenoldopam resulted in an increase in renal plasma flow, a decrease in peak serum creatinine level 72 hours after exposure to contrast, and a trend towards a decreased incidence of CIN ( $21 \%$ and $41 \%$, respectively, $P=0.14$ ). ${ }^{121}$ However, in the multicenter, randomized CONTRAST (fenoldopam mesylate for the prevention of contrast-induced nephropathy) trial of 315 patients undergoing invasive cardiac procedures with an estimated creatinine clearance $<60 \mathrm{~mL} / \mathrm{min}$ treatment with fenoldopam $(0.05 \mu \mathrm{g} / \mathrm{kg} / \mathrm{min}$, titrated up to $0.10 \mu \mathrm{g} / \mathrm{kg} / \mathrm{min}$ ) starting one hour before catheterization and continuing for 12 hours after, versus matching placebo, did not reduce the rate of CIN (33.6\% versus $30.1 \%)$. ${ }^{122}$ No subgroup was identified that demonstrated even a trend toward benefit with fenoldopam.

\section{Theophylline and aminophylline}

Adenosine, a renal vasoconstrictor, has been proposed to interfere with renal function and development of CIN by attenuation of renal blood flow and decrease in glomerular filtration perfusion pressure. Theophylline and aminophylline are nonspecific adenosine (A1) receptor antagonists that may lessen the decrease in renal blood flow and glomerular filtration rate induced by exposure to contrast medium. ${ }^{123}$ Several randomized studies have assessed the possible protective role of theophylline on preservation of renal function in patients undergoing contrast exposure. In a randomized study by Huber et al, prophylactic intravenous administration of theophylline $200 \mathrm{mg}$ reduced the incidence of CIN in 100 patients at risk, as compared with placebo ( $4 \%$ versus $16 \%, P=0.046) .{ }^{124}$ However, in other randomized studies, administration of theophylline did not 
provide any benefit in reduction of CIN rates compared with placebo. ${ }^{120,125,126}$ The results of two published meta-analyses seem to be inconclusive, due to significant heterogeneity in results across individual studies. ${ }^{127,128}$

\section{Calcium channel blockers}

The proposed mechanisms by which calcium antagonists may ameliorate renal damage following exposure to contrast media include favorable effects on renal hemodynamics (reversal of renal vasoconstriction), block of intracellular calcium overload induced by various types of ischemic or toxic stimuli, reduction in renal hypertrophy, modulation of mesangial traffic of macromolecules, and reduction of free radical formation. ${ }^{129}$ Several clinical studies investigated the effect of calcium channel blockers on rates of CIN and provided inconsistent results. In a small, randomized, placebocontrolled study of 35 patients, estimated glomerular filtration rate was preserved in patients treated with nitrendipine but decreased in patients that received placebo. ${ }^{130}$ By contrast, in three other studies, the change in serum creatinine level did not differ significantly with calcium antagonists. ${ }^{131-133}$

\section{$\mathrm{ACl}$ inhibitors and angiotensin receptor blockers}

Given that the ACE inhibitors and angiotensin receptor blockers attenuate afferent arteriolar vasoconstriction, ${ }^{134,135}$ it has been hypothesized that their administration may reduce medullary ischemia and rates of CIN in patients undergoing contrast exposure. The role of the ACE inhibitor, captopril, in the prevention of CIN was prospectively investigated in a small randomized (albeit not placebo-controlled) study of 71 patients with diabetes mellitus undergoing coronary angiography. ${ }^{136}$ Captopril was given at a dose of $25 \mathrm{mg}$ three times daily for three days starting one hour prior to angiography. The glomerular filtration rate increased in the captopril group and decreased in the control group in this study. The increase in creatinine and blood urea nitrogen in the captopril group was significantly less prominent than in the control group. This was accompanied by $79 \%$ lower rates of $\mathrm{CIN}$ in the captopriltreated group compared with the control group. ${ }^{136}$ However, these results were not supported by a retrospective study in 230 patients 65 years of age or older, with baseline renal insufficiency and undergoing coronary angiography, in which the use of an ACE inhibitor was associated with an almost three-fold increase in rates of CIN. ${ }^{137}$ Given this controversy, it cannot currently be concluded that ACE inhibitors are effective in the prevention of $\mathrm{CIN}$ in patients at risk. Moreover, some investigators believe that ACE inhibitor/angiotensin receptor blocker therapy should be discontinued prior to contrast exposure. Yet, in a randomized prospective study of 220 patients with advanced chronic kidney disease (glomerular filtration rate $15-60 \mathrm{~mL} / \mathrm{min} / 1.73 \mathrm{~m}^{2}$ ) receiving chronic treatment with an ACE inhibitor or angiotensin receptor blocker, periprocedural (24 hours prior to and three days after coronary angiography) discontinuation of ACE inhibitor/angiotensin receptor blocker therapy did not confer any protective effect on kidney function or the incidence of CIN. ${ }^{138}$

Hence, there is not enough evidence as yet to support either the administration or withdrawal of ACE inhibitors or angiotensin receptor blockers prior to contrast exposure in patients at risk of CIN.

\section{Atrial natriuretic peptide}

Atrial natriuretic peptide in three different doses failed to prevent CIN in the randomized, placebo-controlled study by Kurnik et al. ${ }^{139}$

\section{Prostaglandin EI}

Based on the finding that patients with CIN have decreased levels of prostaglandins, causing a shift in physiologic vasoconstriction/vasodilatation balance, it was hypothesized that prophylactic administration of prostaglandin E1 might be beneficial in reducing rates of CIN. ${ }^{140} \mathrm{~A}$ double-blind, randomized, placebo-controlled study investigated the effect of intravenous administration of prostaglandin E1 at three different doses. All the groups treated with prostaglandin E1, independently of the given dose, experienced significantly less increase in serum creatinine compared with the placebo group after exposure to contrast media. The most pronounced effect was observed in patients who received the intermediate dose of the drug (20 ng/ $\mathrm{kg} /$ minute). ${ }^{140}$

\section{Statins}

In two retrospective series of patients undergoing cardiac catheterization, pretreatment with statins was associated with lower rates of CIN. ${ }^{141,142}$ However, this was not confirmed in a prospective, randomized, double-blind, placebo-controlled, two-center trial of 247 consecutive patients with chronic renal insufficiency (calculated creatinine clearance $\leq 60 \mathrm{~mL} / \mathrm{min}$ and/or serum creatinine $\geq 1.1 \mathrm{mg} / \mathrm{dL}$ ) undergoing coronary angiography. Patients randomized to $160 \mathrm{mg}$ simvastatin (40 mg orally every 12 hours starting the evening before and ending the morning after the procedure) versus placebo had a similar mean peak increase in serum creatinine at 48 hours after coronary angiography, rates of CIN, and clinical outcomes at one and 6 months. ${ }^{143}$ 


\section{Renal replacement therapy in prevention of contrast-induced nephropathy \\ Hemodialysis}

Iodinated contrast agents are readily dialyzable. The plasma clearance of most modern contrast media is $50-70 \mathrm{~mL} /$ min, with more than $80 \%$ removed from the plasma within 4-5 hours of hemodialysis. ${ }^{144}$ Several studies have examined the effect of hemodialysis in preventing renal function deterioration after exposure to contrast media, in patients with preexisting chronic kidney disease, providing inconsistent results. In two studies, prophylactic hemodialysis, immediately after exposure to contrast media, failed to diminish the rates of CIN or complications. ${ }^{145,146}$ However, in another study, patients were randomized to intravenous hydration alone or hydration plus prophylactic hemodialysis following the procedure. Prophylactic hemodialysis was associated with a less prominent decrease in creatinine clearance within 72 hours of contrast exposure and lower rates of need for subsequent temporary renal replacement therapy or need for long-term dialysis after discharge. ${ }^{147}$

\section{Hemofiltration}

In a prospective, single-center study of 114 patients with preexisting renal failure (serum creatinine $>2 \mathrm{mg} / \mathrm{dL}$ ) undergoing coronary interventions, prophylactic hemofiltration (fluid replacement rate $1000 \mathrm{~mL} /$ hour without weight loss), before and after percutaneous coronary intervention, was compared with hydration alone. Patients assigned to hemofiltration had significantly lower rates of CIN $(5 \%$ versus $50 \%, P<0.001)$, temporary renal replacement therapy ( $3 \%$ versus $25 \%, P<0.001$ ), inhospital mortality (2\% versus $14 \%, P=0.02)$, and one-year mortality $(10 \%$ versus $30, P=0.01) .{ }^{148}$ Another randomized study from the same institution further showed that meticulous hydration combined with hemofiltration both before and after exposure to contrast media versus hemofiltration only after exposure to contrast versus hydration alone was associated with a lower incidence of CIN ( $3 \%$ versus $26 \%$ versus $40 \%$, respectively, $P=0.03)$, requirement for hemodialysis $(0 \%$ versus $10 \%$ and $30 \%, P=0.002)$ and inhospital mortality $(0 \%$ versus $10 \%$ versus $20 \%, P=0.03) .{ }^{149}$

\section{Targeted renal therapy}

Targeted renal therapy is an approach aimed at delivering therapeutic agents directly to the kidneys using a dedicated Benephit $^{\mathrm{TM}}$ (FlowMedica, Fremont, CA) infusion system. This approach provides elevated and sustained concentrations of drugs in the kidneys while minimizing systemic exposure and side effects. In a study of 285 patients at risk for CIN, the actual observed rate of CIN using the infusion of fenoldopam directly into renal arteries was significantly lower than predicted by risk score calculations $(8.1 \%$ actual CIN versus $28.0 \%$ predicted; $P<0.0001) .{ }^{56,150}$

\section{Conclusion}

CIN is an iatrogenic disorder, resulting from physiciandirected administration of contrast media. It is a prevalent condition in patients at risk and is associated with an adverse prognosis. To date, no strategy has been shown to prevent CIN effectively beyond meticulous patient selection with careful risk/benefit analysis, adequate intravenous periprocedural hydration with isotonic saline, and minimizing the amount of contrast agent. While there is no absolutely harmless contrast medium, low osmolar or iso-osmolar contrast agents have a superior safety profile with regard to nephrotoxicity as compared with high osmolar agents, and are at present recommended by the current guidelines. ${ }^{101}$ All patients with chronic kidney disease undergoing contrast exposure should receive preventive hydration with isotonic saline, to be started at least 12 hours before angiography and continued for at least 24 hours afterwards. Repeated exposure to contrast media, within a short time period (3-10 days) should be discouraged whenever possible. Medications known to worsen renal function should be withheld for at least 48 hours preprocedure. Hypotension should be recognized and treated promptly. Prophylactic hemofiltration six hours before complex procedures may be considered in very high-risk patients, although further studies of this invasive modality are needed. Novel therapies, such as controlled hydration combined with forced diuresis, have shown promising initial results, but more data are needed before adopting this modality for CIN prevention.

\section{Disclosure}

The authors report no conflicts of interest in this work.

\section{References}

1. DeFrances CJ, Hall MJ. 2005 National Hospital Discharge Survey. Adv Data. 2007;(385):1-19.

2. Roger VL, Go AS, Lloyd-Jones DM, et al. Heart Disease and Stroke Statistics - 2011 Update: a Report From the American Heart Association. Circulation. 2011;123(4):e18-e209.

3. McCullough PA, Wolyn R, Rocher LL, Levin RN, O’Neill WW. Acute renal failure after coronary intervention: incidence, risk factors, and relationship to mortality. Am J Med. 1997;103(5):368-375. 
4. Rihal CS, Textor SC, Grill DE, et al. Incidence and prognostic importance of acute renal failure after percutaneous coronary intervention. Circulation. 2002;105(19):2259-2264.

5. Solomon RJ, Natarajan MK, Doucet S, et al. Cardiac Angiography in Renally Impaired Patients (CARE) study: a randomized double-blind trial of contrast-induced nephropathy in patients with chronic kidney disease. Circulation. 2007;115(25):3189-3196.

6. Lasser EC, Lyon SG, Berry CC. Reports on contrast media reactions: analysis of data from reports to the US Food and Drug Administration. Radiology. 1997;203(3):605-610.

7. Rudnick MR, Goldfarb S, Wexler L, et al. Nephrotoxicity of ionic and nonionic contrast media in 1196 patients: a randomized trial. The Iohexol Cooperative Study. Kidney Int. 1995;47(1):254-261.

8. Rich MW, Crecelius CA. Incidence, risk factors, and clinical course of acute renal insufficiency after cardiac catheterization in patients 70 years of age or older. A prospective study. Arch Intern Med. 1990; 150(6):1237-1242.

9. Barrett BJ, Parfrey PS. Clinical practice. Preventing nephropathy induced by contrast medium. N Engl J Med. 2006;354(4):379-386.

10. Parfrey PS, Griffiths SM, Barrett BJ, et al. Contrast material-induced renal failure in patients with diabetes mellitus, renal insufficiency, or both. A prospective controlled study. $N$ Engl J Med. 1989;320(3): 143-149.

11. Blank DW, Nanji AA. Ketone interference in estimation of urinary creatinine; effect on creatinine clearance in diabetic ketoacidosis. Clin Biochem. 1982;15(6):279-280.

12. Gerard SK, Khayam-Bashi H. Characterization of creatinine error in ketotic patients. A prospective comparison of alkaline picrate methods with an enzymatic method. Am J Clin Pathol. 1985;84(5):659-664.

13. Arvanitakis Z, Lucas JA, Younkin LH, Younkin SG, Graff-Radford NR. Serum creatinine levels correlate with plasma amyloid beta protein. Alzheimer Dis Assoc Disord. 2002;16(3):187-190.

14. Hyneck ML, Berardi RR, Johnson RM. Interference of cephalosporins and cefoxitin with serum creatinine determination. Am J Hosp Pharm. 1981;38(9):1348-1352.

15. Srisawasdi P, Chaichanajarernkul U, Teerakanjana N, Vanavanan S, Kroll MH. Exogenous interferences with Jaffe creatinine assays: addition of sodium dodecyl sulfate to reagent eliminates bilirubin and total protein interference with Jaffe methods. J Clin Lab Anal. 2010; 24(3):123-133.

16. Tenstad O, Roald AB, Grubb A, Aukland K. Renal handling of radiolabelled human cystatin $\mathrm{C}$ in the rat. Scand J Clin Lab Invest. 1996;56(5):409-414.

17. Ahlstrom A, Tallgren M, Peltonen S, Pettila V. Evolution and predictive power of serum cystatin C in acute renal failure. Clin Nephrol. 2004; 62(5):344-350.

18. Newman DJ, Thakkar H, Edwards RG, et al. Serum cystatin C measured by automated immunoassay: a more sensitive marker of changes in GFR than serum creatinine. Kidney Int. 1995;47(1):312-318.

19. Dharnidharka VR, Kwon C, Stevens G. Serum cystatin C is superior to serum creatinine as a marker of kidney function: a meta-analysis. $\mathrm{Am}$ J Kidney Dis. 2002;40(2):221-226.

20. Rickli H, Benou K, Ammann P, et al. Time course of serial cystatin $\mathrm{C}$ levels in comparison with serum creatinine after application of radiocontrast media. Clin Nephrol. 2004;61(2):98-102.

21. Jayagopal V, Keevil BG, Atkin SL, Jennings PE, Kilpatrick ES. Paradoxical changes in cystatin $\mathrm{C}$ and serum creatinine in patients with hypo- and hyperthyroidism. Clin Chem. 2003;49(4):680-681.

22. Fricker M, Wiesli P, Brandle M, Schwegler B, Schmid C. Impact of thyroid dysfunction on serum cystatin C. Kidney Int. 2003;63(5): 1944-1947.

23. Risch L, Herklotz R, Blumberg A, Huber AR. Effects of glucocorticoid immunosuppression on serum cystatin $\mathrm{C}$ concentrations in renal transplant patients. Clin Chem. 2001;47(11):2055-2059.

24. Briguori C, Visconti G, Rivera NV, et al. Cystatin C and contrastinduced acute kidney injury. Circulation. 2010;121(19):2117-2122.
25. Solomon RJ, Mehran R, Natarajan MK, et al. Contrast-induced nephropathy and long-term adverse events: cause and effect? Clin J Am Soc Nephrol. 2009;4(7):1162-1169.

26. Mori K, Lee HT, Rapoport D, et al. Endocytic delivery of lipocalinsiderophore-iron complex rescues the kidney from ischemia-reperfusion injury. J Clin Invest. 2005;115(3):610-621.

27. Mishra J, Ma Q, Kelly C, et al. Kidney NGAL is a novel early marker of acute injury following transplantation. Pediatr Nephrol. 2006;21(6): $856-863$.

28. Bachorzewska-Gajewska H, Malyszko J, Sitniewska E, Malyszko JS, Dobrzycki S. Neutrophil gelatinase-associated lipocalin (NGAL) correlations with cystatin $\mathrm{C}$, serum creatinine and eGFR in patients with normal serum creatinine undergoing coronary angiography. Nephrol Dial Transplant. 2007;22(1):295-296.

29. Hirsch R, Dent C, Pfriem H, et al. NGAL is an early predictive biomarker of contrast-induced nephropathy in children. Pediatr Nephrol. 2007;22(12):2089-2095.

30. Hemdahl AL, Gabrielsen A, Zhu C, et al. Expression of neutrophil gelatinase-associated lipocalin in atherosclerosis and myocardial infarction. Arterioscler Thromb Vasc Biol. 2006;26(1):136-142.

31. Ichimura T, Bonventre JV, Bailly V, et al. Kidney injury molecule-1 (KIM-1), a putative epithelial cell adhesion molecule containing a novel immunoglobulin domain, is up-regulated in renal cells after injury. J Biol Chem. 1998;273(7):4135-4142.

32. Han WK, Bailly V, Abichandani R, Thadhani R, Bonventre JV. Kidney Injury Molecule-1 (KIM-1): a novel biomarker for human renal proximal tubule injury. Kidney Int. 2002;62(1):237-244.

33. Arici M, Usalan C, Altun B, et al. Radiocontrast-induced nephrotoxicity and urinary alpha-glutathione S-transferase levels: effect of amlodipine administration. Int Urol Nephrol. 2003;35(2):255-261.

34. Beeri R, Symon Z, Brezis M, et al. Rapid DNA fragmentation from hypoxia along the thick ascending limb of rat kidneys. Kidney Int. 1995; 47(6):1806-1810.

35. Hizoh I, Haller C. Radiocontrast-induced renal tubular cell apoptosis: hypertonic versus oxidative stress. Invest Radiol. 2002;37(8): 428-434.

36. Katholi RE, Woods WT Jr, Taylor GJ, et al. Oxygen free radicals and contrast nephropathy. Am J Kidney Dis. 1998;32(1):64-71.

37. Erley CM, Heyne N, Rossmeier S, Vogel T, Risler T, Osswald H. Adenosine and extracellular volume in radiocontrast media-induced nephropathy. Kidney Int Suppl. 1998;67:S192-S194.

38. Yao K, Heyne N, Erley CM, Risler T, Osswald H. The selective adenosine A1 receptor antagonist KW-3902 prevents radiocontrast media-induced nephropathy in rats with chronic nitric oxide deficiency. Eur J Pharmacol. 2001;414(1):99-104.

39. Liss P, Nygren A, Olsson U, Ulfendahl HR, Erikson U. Effects of contrast media and mannitol on renal medullary blood flow and red cell aggregation in the rat kidney. Kidney Int. 1996;49(5):1268-1275.

40. Liss P. Effects of contrast media on renal microcirculation and oxygen tension. An experimental study in the rat. Acta Radiol Suppl. 1997;409: $1-29$.

41. Nygren A, Ulfendahl HR. Effects of high- and low-osmolar contrast media on renal plasma flow and glomerular filtration rate in euvolaemic and dehydrated rats. A comparison between ioxithalamate, iopamidol, iohexol and ioxaglate. Acta Radiol. 1989;30(4):383-389.

42. Sendeski M, Patzak A, Persson PB. Constriction of the vasa recta, the vessels supplying the area at risk for acute kidney injury, by four different iodinated contrast media, evaluating ionic, nonionic, monomeric and dimeric agents. Invest Radiol. 2010;45(8):453-457.

43. Liss P, Nygren A, Hansell P. Hypoperfusion in the renal outer medulla after injection of contrast media in rats. Acta Radiol. 1999;40(5): 521-527.

44. Katzberg RW, Morris TW, Burgener FA, Kamm DE, Fischer HW. 1977 Memorial Award Paper. Renal renin and hemodynamic responses to selective renal artery catheterization and angiography. Invest Radiol. $1990 ; 25(4): 453-460$. 
45. Seeliger E, Flemming B, Wronski T, et al. Viscosity of contrast media perturbs renal hemodynamics. J Am Soc Nephrol. 2007;18(11): 2912-2920.

46. Mockel M, Radovic M, Kuhnle Y, et al. Acute renal haemodynamic effects of radiocontrast media in patients undergoing left ventricular and coronary angiography. Nephrol Dial Transplant. 2008;23(5): 1588-1594.

47. Weisberg LS, Kurnik PB, Kurnik BR. Radiocontrast-induced nephropathy in humans: role of renal vasoconstriction. Kidney Int. 1992; 41(5):1408-1415.

48. Russo D, Minutolo R, Cianciaruso B, Memoli B, Conte G, De Nicola L. Early effects of contrast media on renal hemodynamics and tubular function in chronic renal failure. J Am Soc Nephrol. 1995;6(5): 1451-1458.

49. Cantley LG, Spokes K, Clark B, McMahon EG, Carter J, Epstein FH. Role of endothelin and prostaglandins in radiocontrast-induced renal artery constriction. Kidney Int. 1993;44(6):1217-1223.

50. Clark BA, Kim D, Epstein FH. Endothelin and atrial natriuretic peptide levels following radiocontrast exposure in humans. Am J Kidney Dis. 1997;30(1):82-86.

51. Mikkonen R, Lehto T, Koistinen V, Aronen HJ, Kivisaari L, Meri S. Suppression of alternative complement pathway activity by radiographic contrast media. Scand J Immunol. 1997;45(4):371-377.

52. Modi KS, Rao VK. Atheroembolic renal disease. J Am Soc Nephrol. 2001;12(8):1781-1787.

53. Dangas G, Iakovou I, Nikolsky E, et al. Contrast-induced nephropathy after percutaneous coronary interventions in relation to chronic kidney disease and hemodynamic variables. Am J Cardiol. 2005;95(1): 13-19.

54. Toprak O. Risk markers for contrast-induced nephropathy. Am J Med Sci. 2007;334(4):283-290.

55. Toprak O, Cirit M, Yesil M, et al. Impact of diabetic and pre-diabetic state on development of contrast-induced nephropathy in patients with chronic kidney disease. Nephrol Dial Transplant. 2007;22(3): 819-826.

56. Mehran R, Aymong ED, Nikolsky E, et al. A simple risk score for prediction of contrast-induced nephropathy after percutaneous coronary intervention: development and initial validation. J Am Coll Cardiol. 2004;44(7):1393-1399.

57. Marenzi G, Lauri G, Assanelli E, et al. Contrast-induced nephropathy in patients undergoing primary angioplasty for acute myocardial infarction. J Am Coll Cardiol. 2004;44(9):1780-1785.

58. Freeman RV, O’Donnell M, Share D, et al. Nephropathy requiring dialysis after percutaneous coronary intervention and the critical role of an adjusted contrast dose. Am J Cardiol. 2002;90(10):1068-1073.

59. Nikolsky E, Mehran R, Lasic Z, et al. Low hematocrit predicts contrastinduced nephropathy after percutaneous coronary interventions. Kidney Int. 2005;67(2):706-713.

60. Hill JA, Winniford M, Cohen MB, et al. Multicenter trial of ionic versus nonionic contrast media for cardiac angiography. The Iohexol Cooperative Study. Am J Cardiol. 1993;72(11):770-775.

61. Gruberg L, Mintz GS, Mehran R, et al. The prognostic implications of further renal function deterioration within $48 \mathrm{~h}$ of interventional coronary procedures in patients with pre-existent chronic renal insufficiency. J Am Coll Cardiol. 2000;36(5):1542-1548.

62. Levy EM, Viscoli CM, Horwitz RI. The effect of acute renal failure on mortality. A cohort analysis. JAMA. 1996;275(19):1489-1494.

63. Gruberg L, Mehran R, Dangas G, et al. Acute renal failure requiring dialysis after percutaneous coronary interventions. Catheter Cardiovasc Interv. 2001;52(4):409-416.

64. Hall KA, Wong RW, Hunter GC, et al. Contrast-induced nephrotoxicity: the effects of vasodilator therapy. J Surg Res. 1992;53(4): 317-320.

65. Uddin MA, Rabbani MA, Jafary FH, Bhatti MA, Islam M. Contrast nephropathy in high-risk patients undergoing coronary angiography and intervention. J Coll Physicians Surg Pak. 2005;15(12):791-794.
66. Guitterez NV, Diaz A, Timmis GC, et al. Determinants of serum creatinine trajectory in acute contrast nephropathy. J Interv Cardiol. 2002;15(5):349-354.

67. Lautin EM, Freeman NJ, Schoenfeld AH, et al. Radiocontrast-associated renal dysfunction: incidence and risk factors. AJR Am J Roentgenol. 1991;157(1):49-58.

68. Nikolsky E, Mehran R, Turcot D, et al. Impact of chronic kidney disease on prognosis of patients with diabetes mellitus treated with percutaneous coronary intervention. Am J Cardiol. 2004;94(3):300-305.

69. Manske CL, Sprafka JM, Strony JT, Wang Y. Contrast nephropathy in azotemic diabetic patients undergoing coronary angiography. Am J Med. 1990;89(5):615-620.

70. Birck R, Krzossok S, Markowetz F, Schnulle P, van der Woude FJ, Braun C. Acetylcysteine for prevention of contrast nephropathy: meta-analysis. Lancet. 2003;362(9384):598-603.

71. Cigarroa RG, Lange RA, Williams RH, Hillis LD. Dosing of contrast material to prevent contrast nephropathy in patients with renal disease. Am J Med. 1989;86(6 Pt 1):649-652.

72. Albert SG, Shapiro MJ, Brown WW, et al. Analysis of radiocontrastinduced nephropathy by dual-labeled radionuclide clearance. Invest Radiol. 1994;29(6):618-623.

73. Rosovsky MA, Rusinek H, Berenstein A, Basak S, Setton A, Nelson PK. High-dose administration of nonionic contrast media: a retrospective review. Radiology. 1996;200(1):119-122.

74. Kahn JK, Rutherford BD, McConahay DR, et al. High-dose contrast agent administration during complex coronary angioplasty. Am Heart J. 1990;120(3):533-536.

75. Sherwin PF, Cambron R, Johnson JA, Pierro JA. Contrast dose-tocreatinine clearance ratio as a potential indicator of risk for radiocontrast-induced nephropathy: correlation of $\mathrm{D} / \mathrm{CrCL}$ with area under the contrast concentration-time curve using iodixanol. Invest Radiol. 2005;40(9):598-603.

76. Laskey WK, Jenkins C, Selzer F, et al. Volume-to-creatinine clearance ratio: a pharmacokinetically based risk factor for prediction of early creatinine increase after percutaneous coronary intervention. J Am Coll Cardiol. 2007;50(7):584-590.

77. Nozue T, Michishita I, Iwaki T, Mizuguchi I, Miura M. Contrast medium volume to estimated glomerular filtration rate ratio as a predictor of contrast-induced nephropathy developing after elective percutaneous coronary intervention. J Cardiol. 2009;54(2):214-220.

78. Nyman U, Bjork J, Aspelin P, Marenzi G. Contrast medium dose-to-GFR ratio: a measure of systemic exposure to predict contrastinduced nephropathy after percutaneous coronary intervention. Acta Radiol. 2008;49(6):658-667.

79. Marenzi G, Assanelli E, Campodonico J, et al. Contrast volume during primary percutaneous coronary intervention and subsequent contrastinduced nephropathy and mortality. Ann Intern Med. 2009;150(3): $170-177$.

80. Taliercio CP, Vlietstra RE, Ilstrup DM, et al. A randomized comparison of the nephrotoxicity of iopamidol and diatrizoate in high risk patients undergoing cardiac angiography. J Am Coll Cardiol. 1991;17(2): 384-390.

81. Davidson C, Stacul F, McCullough PA, et al. Contrast medium use. Am J Cardiol. 2006;98(6A):42K-58K.

82. Sharma SK, Kini A. Effect of nonionic radiocontrast agents on the occurrence of contrast-induced nephropathy in patients with mildmoderate chronic renal insufficiency: pooled analysis of the randomized trials. Catheter Cardiovasc Interv. 2005;65(3):386-393.

83. Aspelin P, Aubry P, Fransson SG, Strasser R, Willenbrock R, Berg KJ. Nephrotoxic effects in high-risk patients undergoing angiography. N Engl J Med. 2003;348(6):491-499.

84. Jo SH, Youn TJ, Koo BK, et al. Renal toxicity evaluation and comparison between visipaque (iodixanol) and hexabrix (ioxaglate) in patients with renal insufficiency undergoing coronary angiography: the RECOVER study: a randomized controlled trial. J Am Coll Cardiol. 2006;48(5):924-930. 
85. Laskey W, Aspelin P, Davidson C, et al. Nephrotoxicity of iodixanol versus iopamidol in patients with chronic kidney disease and diabetes mellitus undergoing coronary angiographic procedures. Am Heart J. 2009;158(5):822.e3-828.e3.

86. Mehran R, Nikolsky E, Kirtane AJ, et al. Ionic low-osmolar versus nonionic iso-osmolar contrast media to obviate worsening nephropathy after angioplasty in chronic renal failure patients: the ICON (Ionic versus non-ionic Contrast to Obviate worsening Nephropathy after angioplasty in chronic renal failure patients) study. JACC Cardiovasc Interv. 2009;2(5):415-421.

87. McCullough PA. Contrast-induced acute kidney injury. J Am Coll Cardiol. 2008;51(15):1419-1428.

88. Bartholomew BA, Harjai KJ, Dukkipati S, et al. Impact of nephropathy after percutaneous coronary intervention and a method for risk stratification. Am J Cardiol. 2004;93(12):1515-1519.

89. Berns AS. Nephrotoxicity of contrast media. Kidney Int. 1989;36(4): 730-740.

90. Rudnick MR, Berns JS, Cohen RM, Goldfarb S. Nephrotoxic risks of renal angiography: contrast media-associated nephrotoxicity and atheroembolism - a critical review. Am J Kidney Dis. 1994;24(4): 713-727.

91. Nash K, Hafeez A, Hou S. Hospital-acquired renal insufficiency. Am J Kidney Dis. 2002;39(5):930-936.

92. Solomon R, Werner C, Mann D, D'Elia J, Silva P. Effects of saline, mannitol, and furosemide to prevent acute decreases in renal function induced by radiocontrast agents. $N$ Engl J Med. 1994;331(21): 1416-1420.

93. Trivedi HS, Moore H, Nasr S, et al. A randomized prospective trial to assess the role of saline hydration on the development of contrast nephrotoxicity. Nephron Clin Pract. 2003;93(1):C29-C34.

94. Wróbel W, Sinkiewicz W, Gordon M, Woźniak-Wiśniewska A. Oral versus intravenous hydration and renal function in diabetic patients undergoing percutaneous coronary interventions. Kardiol Pol. 2010; 8(9):1015-1020.

95. Taylor AJ, Hotchkiss D, Morse RW, McCabe J. PREPARED: preparation for Angiography in Renal Dysfunction: a randomized trial of inpatient vs outpatient hydration protocols for cardiac catheterization in mildto-moderate renal dysfunction. Chest. 1998;114(6):1570-1574.

96. Mueller C, Buerkle G, Buettner HJ, et al. Prevention of contrast media-associated nephropathy: randomized comparison of 2 hydration regimens in 1620 patients undergoing coronary angioplasty. Arch Intern Med. 2002;162(3):329-336.

97. Dussol B, Morange S, Loundoun A, Auquier P, Berland Y. A randomized trial of saline hydration to prevent contrast nephropathy in chronic renal failure patients. Nephrol Dial Transplant. 2006; 21(8):2120-2126.

98. Clavijo LC, Pinto TL, Kuchulakanti PK, et al. Effect of a rapid intraarterial infusion of dextrose $5 \%$ prior to coronary angiography on frequency of contrast-induced nephropathy in high-risk patients. Am J Cardiol. 2006;97(7):981-983.

99. Krasuski RA, Beard BM, Geoghagan JD, Thompson CM, Guidera SA. Optimal timing of hydration to erase contrast-associated nephropathy: the OTHER CAN study. J Invasive Cardiol. 2003;15(12): 699-702.

100. Bader BD, Berger ED, Heede MB, et al. What is the best hydration regimen to prevent contrast media-induced nephrotoxicity? Clin Nephrol. 2004;62(1):1-7.

101. Wijns W, Kolh P, Danchin N, et al. Guidelines on myocardial revascularization: the Task Force on Myocardial Revascularization of the European Society of Cardiology (ESC) and the European Association for Cardio-Thoracic Surgery (EACTS). Eur Heart J. 2010;31(20):2501-2555.

102. Merten GJ, Burgess WP, Gray LV, et al. Prevention of contrast-induced nephropathy with sodium bicarbonate: a randomized controlled trial. JAMA. 2004;291(19):2328-2334.
103. Briguori C, Airoldi F, D'Andrea D, et al. Renal Insufficiency Following Contrast Media Administration Trial (REMEDIAL): a randomized comparison of 3 preventive strategies. Circulation. 2007;115(10): 1211-1217.

104. Ozcan EE, Guneri S, Akdeniz B, et al. Sodium bicarbonate, $\mathrm{N}$-acetylcysteine, and saline for prevention of radiocontrast-induced nephropathy. A comparison of 3 regimens for protecting contrastinduced nephropathy in patients undergoing coronary procedures. A single-center prospective controlled trial. Am Heart J. 2007;154(3): 539-544.

105. Brar SS, Shen AY, Jorgensen MB, et al. Sodium bicarbonate vs sodium chloride for the prevention of contrast medium-induced nephropathy in patients undergoing coronary angiography: a randomized trial. JAMA. 2008;300(9):1038-1046.

106. From AM, Bartholmai BJ, Williams AW, Cha SS, Pflueger A, McDonald FS. Sodium bicarbonate is associated with an increased incidence of contrast nephropathy: a retrospective cohort study of 7977 patients at Mayo Clinic. Clin J Am Soc Nephrol. 2008;3(1):10-18.

107. Brezis M, Rosen S. Hypoxia of the renal medulla - its implications for disease. N Engl J Med. 1995;332(10):647-655.

108. Stevens MA, McCullough PA, Tobin KJ, et al. A prospective randomized trial of prevention measures in patients at high risk for contrast nephropathy: results of the P.R.I.N.C.E. Study. Prevention of Radiocontrast Induced Nephropathy Clinical Evaluation. J Am Coll Cardiol. 1999;33(2):403-411.

109. Weinstein JM, Heyman S, Brezis M. Potential deleterious effect of furosemide in radiocontrast nephropathy. Nephron. 1992;62(4): 413-415.

110. Bartorelli AL, Ferrari C, Trabattoni D, et al. TCT-332: FurosemideInduced Diuresis with Matched Hydration Compared to Standard Hydration for Prevention of Contrast-Induced Nephropathy. The MYTHOS trial. J Am Coll Cardiol. 2010;56:B77.

111. Briguori C, Visconti G, Ricciardelli B, Condorelli G; REMEDIAL II Investigators. Renal insufficiency following contrast media administration trial II (REMEDIAL II): RenalGuard system in high-risk patients for contrast-induced acute kidney injury: rationale and design. EuroIntervention. 2011;6(9):1117-1122.

112. Tepel M, van der Giet M, Schwarzfeld C, Laufer U, Liermann D, Zidek W. Prevention of radiographic-contrast-agent-induced reductions in renal function by acetylcysteine. $N$ Engl J Med. 2000; 343(3):180-184.

113. Diaz-Sandoval LJ, Kosowsky BD, Losordo DW. Acetylcysteine to prevent angiography-related renal tissue injury (the APART trial). Am J Cardiol. 2002;89(3):356-358.

114. Briguori C, Manganelli F, Scarpato P, et al. Acetylcysteine and contrast agent-associated nephrotoxicity. J Am Coll Cardiol. 2002;40(2): 298-303

115. Webb JG, Pate GE, Humphries KH, et al. A randomized controlled trial of intravenous $\mathrm{N}$-acetylcysteine for the prevention of contrastinduced nephropathy after cardiac catheterization: lack of effect. $\mathrm{Am}$ Heart J. 2004;148(3):422-429.

116. Thiele H, Hildebrand L, Schirdewahn C, et al. Impact of high-dose $\mathrm{N}$-acetylcysteine versus placebo on contrast-induced nephropathy and myocardial reperfusion injury in unselected patients with ST-segment elevation myocardial infarction undergoing primary percutaneous coronary intervention. The LIPSIA-N-ACC (Prospective, Single-Blind, Placebo-Controlled, Randomized Leipzig Immediate PercutaneouS Coronary Intervention Acute Myocardial Infarction N-ACC) Trial. J Am Coll Cardiol. 2010;55(20): 2201-2209.

117. ACT Trial Investigators. Rationale, design, and baseline characteristics of the Acetylcystein for Contrast-Induced nephropaThy (ACT) trial: a pragmatic randomized controlled trial to evaluate the efficacy of acetylcysteine for the prevention of contrast-induced nephropathy. Trials. 2009;10:38. 
118. Hoffmann U, Fischereder M, Kruger B, Drobnik W, Kramer BK. The value of $\mathrm{N}$-acetylcysteine in the prevention of radiocontrast agent-induced nephropathy seems questionable. J Am Soc Nephrol. 2004; 15(2):407-410.

119. Gare M, Haviv YS, Ben-Yehuda A, et al. The renal effect of low-dose dopamine in high-risk patients undergoing coronary angiography. J Am Coll Cardiol. 1999;34(6):1682-1688.

120. Abizaid AS, Clark CE, Mintz GS, et al. Effects of dopamine and aminophylline on contrast-induced acute renal failure after coronary angioplasty in patients with preexisting renal insufficiency. $\mathrm{Am} \mathrm{J}$ Cardiol. 1999;83(2):260-263.

121. Tumlin JA, Wang A, Murray PT, Mathur VS. Fenoldopam mesylate blocks reductions in renal plasma flow after radiocontrast dye infusion: a pilot trial in the prevention of contrast nephropathy. Am Heart $J$. 2002;143(5):894-903.

122. Stone GW, McCullough PA, Tumlin JA, et al. Fenoldopam mesylate for the prevention of contrast-induced nephropathy: a randomized controlled trial. JAMA. 2003;290(17):2284-2291.

123. Kolonko A, Wiecek A, Kokot F. The nonselective adenosine antagonist theophylline does prevent renal dysfunction induced by radiographic contrast agents. J Nephrol. 1998;11(3):151-156.

124. Huber W, Ilgmann K, Page M, et al. Effect of theophylline on contras material-nephropathy in patients with chronic renal insufficiency: controlled, randomized, double-blinded study. Radiology. 2002 223(3):772-779.

125. Erley CM, Duda SH, Rehfuss D, et al. Prevention of radiocontrastmedia-induced nephropathy in patients with preexisting renal insufficiency by hydration in combination with the adenosine antagonist theophylline. Nephrol Dial Transplant. 1999;14(5):1146-1149.

126. Shammas NW, Kapalis MJ, Harris M, McKinney D, Coyne EP. Aminophylline does not protect against radiocontrast nephropathy in patients undergoing percutaneous angiographic procedures. J Invasive Cardiol. 2001;13(11):738-740.

127. Ix JH, McCulloch CE, Chertow GM. Theophylline for the prevention of radiocontrast nephropathy: a meta-analysis. Nephrol Dial Transplant. 2004;19(11):2747-2753.

128. Bagshaw SM, Ghali WA. Theophylline for prevention of contrastinduced nephropathy: a systematic review and meta-analysis. Arch Intern Med. 2005;165(10):1087-1093.

129. Neumayer HH, Gellert J, Luft FC. Calcium antagonists and renal protection. Ren Fail. 1993;15(3):353-358.

130. Neumayer HH, Junge W, Kufner A, Wenning A. Prevention of radiocontrast-media-induced nephrotoxicity by the calcium channel blocker nitrendipine: a prospective randomised clinical trial. Nephrol Dial Transplant. 1989;4(12):1030-1036.

131. Carraro M, Mancini W, Artero M, et al. Dose effect of nitrendipine on urinary enzymes and microproteins following non-ionic radiocontrast administration. Nephrol Dial Transplant. 1996;11(3):444-448.

132. Khoury Z, Schlicht JR, Como J, et al. The effect of prophylactic nifedipine on renal function in patients administered contrast media. Pharmacotherapy. 1995;15(1):59-65.

133. Spangberg-Viklund B, Berglund J, Nikonoff T, Nyberg P, Skau T, Larsson R. Does prophylactic treatment with felodipine, a calcium antagonist, prevent low-osmolar contrast-induced renal dysfunction in hydrated diabetic and nondiabetic patients with normal or moderately reduced renal function? Scand J Urol Nephrol. 1996;30(1):63-68.
134. Denton KM, Fennessy PA, Alcorn D, Anderson WP. Morphometric analysis of the actions of angiotensin II on renal arterioles and glomeruli. Am J Physiol. 1992;262(3 Pt 2):F367-F372.

135. Hollenberg NK, Swartz SL, Passan DR, Williams GH. Increased glomerular filtration rate after converting-enzyme inhibition in essential hypertension. $N$ Engl J Med. 1979;301(1):9-12.

136. Gupta RK, Kapoor A, Tewari S, Sinha N, Sharma RK. Captopril for prevention of contrast-induced nephropathy in diabetic patients: a randomised study. Indian Heart J. 1999;51(5):521-526.

137. Cirit M, Toprak O, Yesil M, et al. Angiotensin-converting enzyme inhibitors as a risk factor for contrast-induced nephropathy. Nephron Clin Pract. 2006;104(1):c20-c27.

138. Rosenstock JL, Bruno R, Kim JK, et al. The effect of withdrawal of ACE inhibitors or angiotensin receptor blockers prior to coronary angiography on the incidence of contrast-induced nephropathy. Int Urol Nephrol. 2008;40(3):749-755.

139. Kurnik BR, Allgren RL, Genter FC, Solomon RJ, Bates ER, Weisberg LS. Prospective study of atrial natriuretic peptide for the prevention of radiocontrast-induced nephropathy. Am J Kidney Dis. 1998;31(4) 674-680.

140. Sketch MH Jr, Whelton A, Schollmayer E, et al. Prevention of contrast media-induced renal dysfunction with prostaglandin E1: a randomized, double-blind, placebo-controlled study. Am J Ther. 2001;8(3):155-162.

141. Attallah N, Yassine L, Musial J, Yee J, Fisher K. The potential role of statins in contrast nephropathy. Clin Nephrol. 2004;62(4):273-278.

142. Khanal S, Attallah N, Smith DE, et al. Statin therapy reduces contrastinduced nephropathy: an analysis of contemporary percutaneous interventions. Am J Med. 2005;118(8):843-849.

143. Jo SH, Koo BK, Park JS, et al. Prevention of radiocontrast mediuminduced nephropathy using short-term high-dose simvastatin in patients with renal insufficiency undergoing coronary angiography (PROMISS) trial - a randomized controlled study. Am Heart J. 2008;155(3):499. e1-e8.

144. Dawson P. Contrast agents in patients on dialysis. Semin Dial. 2002; 15(4):232-236

145. Vogt B, Ferrari P, Schonholzer C, et al. Prophylactic hemodialysis after radiocontrast media in patients with renal insufficiency is potentially harmful. Am J Med. 2001;111(9):692-698.

146. Lehnert T, Keller E, GondolfK, Schaffner T, Pavenstadt H, Schollmeyer P. Effect of haemodialysis after contrast medium administration in patients with renal insufficiency. Nephrol Dial Transplant. 1998;13(2):358-362.

147. Lee PT, Chou KJ, Liu CP, et al. Renal protection for coronary angiography in advanced renal failure patients by prophylactic hemodialysis. A randomized controlled trial. J Am Coll Cardiol. 2007; 50(11):1015-1020.

148. Marenzi G, Marana I, Lauri G, et al. The prevention of radiocontrastagent-induced nephropathy by hemofiltration. N Engl J Med. 2003 349(14):1333-1340.

149. Marenzi G, Lauri G, Campodonico J, et al. Comparison of two hemofiltration protocols for prevention of contrast-induced nephropathy in high-risk patients. Am J Med. 2006;119(2):155-162.

150. Weisz G, Filby SJ, Cohen MG, et al. Safety and performance of targeted renal therapy: the Be-RITe! Registry. J Endovasc Ther. 2009; $16(1): 1-12$

International Journal of Nephrology and Renovascular Disease

\section{Publish your work in this journal}

The International Journal of Nephrology and Renovascular Disease is an international, peer-reviewed open-access journal focusing on the pathophysiology of the kidney and vascular supply. Epidemiology, screening, diagnosis, and treatment interventions are covered as well as basic science, biochemical and immunological studies. The journal welcomes

\section{Dovepress}

original research, clinical studies, reviews \& evaluations, expert opinion and commentary, case reports and extended reports. The manuscript management system is completely online and includes a very quick and fair peerreview system, which is all easy to use. Visit http://www.dovepress.com/ testimonials.php to read real quotes from published authors 